Studies EAJMBS January-March 2022, Vol. 2, No. 1, pp. 1-6

ISSN: 2799-2276 (Online). Published by G-Card

DOI: https://doi.org/10.46606/eajmbs2022v02i01.0004

URL: https://eajmbs.ac.tz/

\title{
Challenges Facing School Heads in Controlling Finances among Bukombe District Public Secondary Schools, Tanzania
}

\author{
Ruharara Nelius * \\ ORCID: https://orcid.org/0000-0002-5518-0614 \\ Department of Education Foundations \\ St. Augustine University of Tanzania \\ Daniel Onyango, PhD \\ ORCID: https://orcid.org/0000-0002-5381-226X \\ Department of Education Foundations \\ St. Augustine University of Tanzania \\ *Corresponding Mail: neliusr3@gmail.com

\begin{abstract}
Copyright resides with the author(s) in terms of the Creative Commons Attribution CC BY-NC 4.0.
\end{abstract} \\ The users may copy, distribute, transmit and adapt the work, but must recognize the author(s) and the \\ East African Journal of Management and Business Studies

\begin{abstract}
The purpose of this study was to investigate on the challenges facing school heads in controlling finances among public secondary schools in Bukombe District, Tanzania. The study employed a mixed research approach using Convergent parallel design. The population of the study was 368 education stakeholders. The sample size included 1 Education Officer, 1 District Auditor, 17 Board members, 3 School heads, 3 school Bursars and 54 Teachers. The sample was obtained by using simple random and purposive sampling techniques. Quantitative data was analyzed by using descriptive analysis with the help of SPSS version 20. For qualitative data, thematic approach was used. The study revealed different challenges facing heads of schools in implementing financial control measures including lack of training and transparency, inadequate finances and poor cooperation with stakeholders. The study recommends that the heads of schools should be helped to acquire knowledge and skills necessary for effective financial management.
\end{abstract}

Keywords: Financial Control; School Heads; management; accountability; resources.

How to cite: Nelius, R., and Onyango, D. (2022). Challenges Facing School Heads in Controlling Finances in Bukombe District Public Secondary Schools, Tanzania. East African Journal of Management and Business Studies 2(1), 1-6. Doi: https://doi.org/10.46606/eajmbs2021v02i01.0004.

\section{Introduction}

Financial control deals with organizations' ambition to use funds and to manage financial resources effectively through determined accountability procedures. It is a base for the success of any organization (Fung, 2015). According to Ozmete and Hira (2011), financial control measures refer to the acceptable practices supporting the overall activities of the organization. Effective financial control enables school to achieve desired goals.
Watson and Head (2010) stated that financial control is all about managing, controlling and organizing finances in better ways towards the attainment of organizational targets. It deals with appropriate distribution and utilization of available financial resources. The main aim of financial control is to realize better allocation and utilization of scare financial resources. Financial control is therefore an important activity that leads to making sure that schools attain their purposes. Ogbonnaya (2011) argued that the main aim of financial control is to make sure that funds 
are utilized in the most efficient and effective manner. It is therefore the responsibility of educational administrators to manage financial resources appropriately in order to achieve better educational outcomes.

To ensure financial control in government secondary schools, research in America recommended that serious changes be made to improve the administrative quality over financial resources by giving schools power for financial decisions, particularly to utilize funds for effective school performance (Stiefel, Schwartsz, Portas \& Kim, 2003) as cited by Ryoba (2019). However, the schools faced difficulties in the formulation of school budgets since most of school leaders possessed inadequate knowledge and skills on financial management.

A study in France regarding school management skills and financial resources established that in spite of the efforts placed in provision of financial resources intended to bring about improvement on delivery of services, resources were mismanaged and misallocated by those in the system due to low levels of accountability and transparency (Crouch \& Winker, 2008).

In the African context, particularly South Africa, a study by Mpolokeng (2011) revealed that there are many school heads and members of schools management boards who had inadequate knowledge on financial control systems. They could not find appropriate solutions to different financial problems that arose. Furthermore, poor controlling of school finance had been one of many problems faced by school heads. This is due to lack of training and or skilled personnel which caused poor controlling of schools funds.

A study in Kenya by Nyaegah (2011) established that Kenya's free primary education faced serious troubles, including cases of massive fraud. Some donors stopped funding until those who stole the funds were made accountable. The author explained that internal control is affected by board members, administrators and staff who are charged of ineffective and inefficient running of institutions. Thus, without clear internal controls, schools will not produce desired results.

According to the URT (2006), different programs were established to translate the 1995 Tanzania Educational and Training Policy (TETP) and Education Sector Development Program (ESDP) whose aim was to provide the school heads with skills on how to control finances. According to MOEC Guideline (2004), school heads have the following responsibilities: to ensure effective financial control, to involve school management teams in the process of controlling school finance, to open school bank account, to operate according to guidelines from the Ministry and to submit documents concerning financial activities to relevant authorities.

Rena (2011) conducted a study on challenges facing provision of quality education in Papua New Guinea. The study found that there were challenges in controlling school funds from national level to school level and there was an urgent need to improve the situation in order for objectives of education to be realized.

Kurume and Yoshida (2010) investigated on education quality improvement and school management in Ghana and found that school heads had to use their own money in managing schools; big number of them ended up with debts that might take time to recover. This was because most of schools were not availed with funds and in some cases, the amount provided was not enough for the big number of students.

A study by Alemayehu (2015) in Ethiopia on preparation and implementation of annual education plans in selected secondary schools involved 132 respondents including teachers, viceprincipals and supervisors. The study revealed that there is poor coordination of educational programs and projects due to lack of participation of stakeholders. Therefore stakeholders' involvement in financial is a vital for schools to accomplish school goals.

In Zimbabwe, Nyandoro (2003) examined the effectiveness of school development committees in financial management. The findings revealed that school development committees were not effective in controlling funds due to poor systems of financial control. The study recommended training of head teachers on financial management and control. In Kenya, Njweru (2004) conducted a study on financial management practices of the head teachers in public secondary schools. The study found out that most public secondary school head teachers had poor financial controlling skills.

In Tanzania, literature reveals that most of education stakeholders such as local citizens, 
government officials and village leaders are not involved in financial control initiatives at schools (Simon, 2014). Gaudiose (2017) conducted a study on effectiveness of financial management system in Tanzanian government secondary schools. The study found that most of the funds were not well controlled. Other challenges included inadequate funds to meet the school needs. Based on this background, this study sought to investigate on challenges facing school heads in Bukombe District in controlling finances. The study was guided by the following research question: What challenges are faced by school heads in Controlling Finances among Public Secondary Schools in Bukombe District?

\section{Research Methodology \\ Research Design}

The study employed a mixed research approach using the Convergent Parallel Design. This is a design that combines qualitative and quantitative data in order to provide comprehensive analysis of the research problems. The design was useful in this study as it allowed the researcher to collect data and then analyzed it separately and integrated the information in the interpretation of the overall results.
The population of the study was 368 education stakeholders as seen in table 1 . The sample size was 79 respondents including 1 Education Officer, 1 District Auditor, 17 Board members, 3 School heads, 3 school Bursars and 54 teachers who were obtained using purposive and simple random sampling as seen in Table 1.

\section{Data Collection Instruments Interview}

According to Kothari (2004) interview involves presentation of oral information from respondents. The advantages of interview include quick feedback and flexibility of respondents. This method involved heads of the schools, school bursars, the district auditor and the district education officer.

\section{Questionnaire}

The researcher distributed the questionnaire to teachers and School Management Board (SMB) members. Firstly the researcher explained the study purpose and significance of the study. Secondly the researcher took the respondents through various sections of the questionnaire and instructed how to complete it. Thereafter the questionnaire was distributed to the respondents and they were given time to complete it.

\section{Population and Sampling}

Table1: Distribution of respondents in sample size

\begin{tabular}{lccc}
\hline Category & Population & Technique & Sample size \\
\hline DEO & 1 & Purposively & 1 \\
District auditor & 1 & Purposively & 1 \\
Head teachers & 14 & Purposively & 3 \\
Teachers & 256 & Simple Randomly & 54 \\
SMB & 84 & Simple randomly & 17 \\
School Bursar & 12 & Purposively & 3 \\
Total & $\mathbf{3 6 8}$ & & $\mathbf{7 9}$ \\
\hline
\end{tabular}

\section{Validity and Reliability}

The researchers used content validity. Content validity is the extent to which a measure represents all facets of a given construct. The questionnaire was given to five research experts in the faculty of education at the St. Augustine University of Tanzania who went through the questionnaire and were satisfied that items were related to the issues under investigation, after a thorough analysis.

Inter-rater reliability was used to ensure accuracy of the research instruments. Teachers and heads of schools were provided with the same questionnaire and were asked to rate the items.
The rating was almost similar and this was an indication that there was consistency.

\section{Data Analysis Procedure}

Qualitative data was recorded using sound recorder and was later transcribed for analysis. Quantitative data which was obtained from questionnaire was analyzed using descriptive statistics with the help of the Statistical Software called Statistical Package for Social Science (SPSS) version 20 .

\section{Results and Discussion}

Research Question What challenges are faced by School Heads in Controlling Finances among Public Secondary Schools in Bukombe District? 
When respondents were asked to list challenges they faced in the process of financial control in their respective schools, the following challenges were listed:

\section{Poor of Budgetary Skills}

Through questionnaire, it was revealed that school heads lacked budgetary skills. Majority of school heads did not possess the budgetary skills. In exploring further about head teachers' lack of budgetary skills, it was revealed by the District Education Officer that: "we normally propose names of school heads to the Regional Educational officer who appoints the school heads on behalf of the Regional Administrative Secretary." While the findings suggest that the selected heads of schools did not possess budgetary skills, the District Education officer suggested that "the election of school heads should consider experience in leadership and prior knowledge on budgetary and accounting procedures." Therefore, it is important to consider leadership experience and financial management skills as prerequisites for one to be elected as school head.

\section{Inadequate Funds for School Operation}

School management team and teachers indicated that their schools did not have adequate and sustainable funds for daily activities. Data collected through interview with school heads revealed that a certain "school gets Tsh. $320,000 /=$ as administrative funds from the government of which I have to pay salaries Tsh. 80.000 for watchmen per month and remain with Tsh. 240,000/= for administrative activities." Therefore, the fund is not enough to run school daily activities. Respondents further added that although the number of students increases, funds that comes to school accounts decreases. This cause school heads to face more difficulties in managing and controlling financial resources at schools.

These findings correspond with Allis (2014) who stated that finances are important organizational resources that no organization has ever succeeded without it. Therefore, it becomes very important for institutions, organizations and business entities to consider financial control in order to enhance their performance and mitigate exposure to financial risks. Hence, the growth and development of educational sector including public secondary schools is depends on how well finances are managed and controlled.

During budgeting, funds are allocated to various budget lines according to specific objectives for a particular year. If there is mismanagement, certain budget items will not be funded; and therefore some objectives of a school will not be realized. This corresponds with Horvat (2011) who says that if the school has no financial plan there is a risk that the funds for the action of the school are not properly planned and harmonized with the schools work program. This agrees again with Ogbonnaya ( 2011) who insists that the main purpose of financial control is to ensure that funds are utilized in the most efficient and effective manner it is a responsibility of educational administrators to use available financial resource in prudently for the attainment of institutional objectives. Bad management of funds leads to embezzlement, diversion of funds from prioritized projects and misappropriations. This means that the bases for preparing a financial plan and the intended use of funds according to individual programs in the financial plan or their explanations are not correspondingly shown. It is impossible to report on achieved objectives and results at the end of the year if there are the correspondingly adopted plan, therefore school management board and teachers know the importance of financial controls.

\section{Poor Accountability and Transparency}

Results show that 28.2 percent of respondents revealed poor involvement of teachers and school board members in budget formulation and implementation. This shows how school stakeholders are not involved in financial management for example budgetary processes. This means that respondents thought that through involving stakeholders in financial control measures it enables schools to use its meager resources effectively and therefore it is able to attain its specific goals. This argument is in agreement with Maronga, Weda and Kengere (2013) as they noted that the government should influence good financial management in schools so as to help a school to achieve its goals. This can be done through adherence to financial regulations and policies which includes: regular auditing, credit management and inventory management. These views point out that financial management deals with planning and controlling of financial resources than allocation of the 
resources. Respondents further revealed the challenge of poor accountability and transparency whereby some school heads do made decisions without consulting with school stakeholders. This implies that majority of school heads do not consult before initiating certain financial transactions or implementing major projects. This points to the need for a head of school to regularly consult SBM when drawing huge amounts of money and involve SBM in school procurement decisions instead of acting as a lone ranger. This will ensure that there is effective financial control. The basic objective of financial control is optimum allocation and use of available scare resources, the scarcest resources is money. Financial control is an indispensable activity that ensures that the school meets its goals (Rabousky, 2011).

\section{Conclusions and Recommendations Conclusions}

The study concludes that school heads faced many challenges in the process of controlling funds. These include poor budgetary skills, inadequate funds for school operations and poor accountability and transparency. Because heads had poor budgetary skills, they could not control expenses and make relevant financial decisions related to school operations such as procurement. Financial control becomes difficult where there are inadequate funds as core activities of a school such as curriculum implementation are affected, which leads to poor academic performance. Involvement of other stakeholders in financial control is also important as it enhances accountability and transparency in the utilization of meager school resources towards realization of school objectives.

\section{Recommendations}

Based on the conclusions of this study, it is recommended that during the appointment of school heads preference should be given to those who have knowledge and skills in financial management. This will enable them to effectively use tools such as budgets to enable schools to realize their goals. It will also enable them to be transparent and accountable while controlling school financial resources. Where heads do not have financial control skills, they should be trained on financial control strategies. School heads should be prevailed upon to work with teachers, members of the school management team as well as school bursars in the usage of funds to eliminate lack of transparency and accountability. Schools heads should face sanctions if they don't cooperate. Through inservice training and on job training, skills which will help them to manage school finances properly.

\section{References}

Alemayehu, O. (2015). Preparation and Implementation of Annual Educational plan in selected Secondary School plan in Selected Secondary school of lluababora Zone (Published Master's thesis) University of Addis Ababa, Ethiopia.

Allis, R. P. (2014). Financial Management: Financial Ratio Analysis. Zero to one Million. Journal of Response Managerial Auditing, 9 (7), 21-28.

Crouch, L., \& Winkler, D. (2008). Governance, Management and Financing of Education for All: Basic Frame Works and Case Studies: Paris: UNESCO.

Fung, L. (2015). Financial Management. London School of Economics and Political Science (L. 56), London. London School of Economics and Political Science.

Gaudiose, R. F. B. (2017). An Assessment on the Effectiveness of Financial Management System in Tanzania Government Secondary School in East Region, (Published Master's Thesi). Open University, Tanzania.

Horvat, T. (2011). Transferring Internal Control Knowledge from Legislation to School Managements, Slovenia. International Journal of Scientific Research and Management, 6(10), 125-140.

Kothari, C. R. (2004). Research Methodology: Methods and Techniques, $\left(2^{\text {nd }} e d.\right)$. New Delhi. Age International (p) Ltd.

Kurume, M. \& Yashida, K. (2010). A Preliminary Investigation into educational Quality Improvement and School Management Efficiency. The Case of Capitation Grant in Ghana.

Maronga, E. Weda, C. W. Kengere, D. (2013). An Investigation on the Influence of Government Financial Management on Kenyan Public Secondary Schools: A Case of Saneta Division. International Journal 
of Scientific \& Technology Research, 2 (9), 96-98.

MOEC (2004). Guidelines for Monitoring Construction under Secondary Education Development Plan.

Mpolokeng, T. E. (2011).The Effectiveness of Financial Management in School Centro University of Technology, Free State Welkon Campus.

Njweru, J. W. (2004). Financial Management Practices of the Head Teachers in Public Secondary School in Central Division Embu District, Kenya, Nairobi East African Publishers.

Nyandoro, C. M. (2003). Effect of Internal Controls on Financial Performance of Deposit taking Savings and Credit Cooperative Societies: School of Business University of Nairobi Publishers.

Nyaegah, J. (2011). Challenges Facing Management of Free Primary Education in Kenya: A Case of Nyamira County Kenya. International Journal of Business and Management Tomorrow, 6(4), 123-130.

Ogbonnaya, N. I. (2011). Foundation of Education Finance. Onitsha: CAP.

Ozmete, E. Hira, T. (2011). The Role of Parental Influence and Psychological
Characteristics in Responsible Financial behaviors among Adults. The Journal \& Consumer Affairs, 1(2) 49-54.

Rabousky, T. (2011). Accountability in Higher Education: Exploring Impacts on State Budgets and Institutional Spending. University of Oklahoma, U.S.A.

Rena, R, (2011). Challenges for Quality Primary Education in Papua New Guinea, A case study .Educational Research International. 2011 (485634), doi: 10.1155 /201 $1 / 485634$.

Ryoba, C, B. (2019). Formulation and Implementation of Budgets in Public Secondary Schools in Bukombe, Tanzania: St Augustine University of Tanzania, Unpublished Thesis.

Simon, M.J. (2014). An analysis of the Participation of Citizens in Budgeting process in Local Government in Tanzania: The case of Ngara District Council. (Published Master's Thesis)

URT (2006). The Economic Survey 2005. Dar es salaam: Ministry of Planning Economy and Empowement.

Watson, C. \& Head, D. (2010). The Budget kit: The common cents Money Management work $\left(6^{\text {th }}\right.$ ed). Wokingham: Kaplan Publishing. 